\title{
ANTIOXIDANT AND ANTICANCER ACTIVITY OF METHANOLIC EXTRACT FROM STEPHANIA ELEGANS
}

\author{
RAVIN SHARMA", GOURAV CHANDAN"1, ANTERPREET CHAHAL, REENA V. SAINI*
}

Animal Biotechnology Laboratory, Faculty of Applied Sciences and Biotechnology Shoolini University of Biotechnology and Management Sciences, Bajhol, Solan, Himachal Pradesh, India

Email: reenasaini@shooliniuniversity.com

Received: 17 Nov 2016 Revised and Accepted: 21 Dec 2016

\section{ABSTRACT}

Objective: The present work was aimed to investigate the in vitro antioxidant and anti-cancer activities of methanolic extract of Stephania elegans, an unexplored species from Menispermaceae family.

Methods: The methanolic extract of S. elegans tubers was prepared and phytochemical screening and total phenolic content were analyzed by using standard methods. In vitro, antioxidant potential of methanolic extract was determined by 2-2'-azinobis (3-ethyl-benzothiazoline-6-sulfonic acid) (ABTS) and ferric reducing antioxidant power (FRAP) assays. Cytotoxicity against human breast cancer cell line, Michigan Cancer Foundation-7 type (MCF-7) was evaluated by 3-(4,5 dimethylthiazol-2-yl)-2, 5-diphenyl tetrazolium bromide) (MTT) assay.

Results: Preliminary phytochemical screening revealed the presence of alkaloids, flavonoids, carbohydrates, tannins, terpenoids, steroids, and saponins in the methanolic extract of $S$. elegans tubers. The total phenolic content in the methanolic extract was $23.0 \pm 0.06$ mg GAE/g (dry mass). As revealed by ABTS assay, the methanolic extract of plant tubers showed significant radical scavenging activity (IC $5041.66 \pm 0.015 \mu \mathrm{g} / \mathrm{ml}$ ). The reducing power activity of the extract increased with the concentration of the extract. MTT assay indicated that $S$. elegans has potent cytotoxic activity towards MCF-7 cells (IC $50158.7 \pm 0.13 \mu \mathrm{g} / \mathrm{ml}$ ).

Conclusion: This is the first study demonstrating the antioxidant and anticancer capabilities of the methanolic extract of $S$. elegans. This study also provides a significant basis for further isolation and characterization of bioactive compounds from S. elegans.

Keywords: S. elegans, Anti-cancer, Antioxidant, FRAP, MCF-7

(C) 2017 The Authors. Published by Innovare Academic Sciences Pvt Ltd. This is an open access article under the CC BY license (http://creativecommons.org/licenses/by/4. 0/) DOI: http://dx.doi.org/10.22159/ijpps.2017v9i2.16204

\section{INTRODUCTION}

Cancer is a hyperproliferative condition where cellular homeostasis of a healthy cell fail, leading to activation of numerous genes that are actively involved in survival, cell cycle, metastasis, and angiogenesis. It continues to be a global threat, the greatest cause of mortality and morbidity worldwide [1-3]. A number of novel concepts have been developed for therapeutic intervention in malignant diseases with the aim of recognising specific targets and overcoming the resistance against existing cytotoxic treatments. The numerous cancer cure modalities include surgery, anti-tumor medications and some targeted therapies including the use of radiation and Photodynamic therapy $[4,5]$. Advanced therapies designed to stimulate the effector pathways involved in cell death, including apoptosis could be utilised as an effective strategy for cancer management [6]. Deploying plant-derived compounds or phytochemicals to the work is one such promising approach. The use of plantderived bioactive compounds for anticipation, mitigation and therapeutics for cancer have been applied extensively. Various researchers have recognised species of plants that have established anticancer activities, especially those that have been used in herbal medicine in developing countries [7-9]. The natural compounds isolated from medicinal plants are believed to be major leads in the designing of anticancer medications. Screening of medicinal plants and their bioactive constituents for several biological activities, such as anticancer activity, has been a key research area since last few decades [10].

Free radicals and related species have attracted a great deal of attention in recent years. Reactive oxygen species (ROS)/Reactive nitrogen species (RNS) and other free radicals are responsible for countless diseases, such as arteriosclerosis, heart diseases, diabetes, aging process and cancer $[11,12]$. ROS/RNS can activate the initiation, promotion and advancement phases of cancer by damaging DNA bases and the deoxyribose backbone leading to severe mutations in fundamental genes $[13,14]$. A lot of studies have reported that cancers are associated with ROS production [15]. Antioxidant defences encompass a variety of distinct compounds and enzymes that are linked together through their capacity to neutralise and scavenge ROS. Phenolic extracts or isolated polyphenols from different plants have been studied for their anti-cancerous effects on various cell lines representing different stages of cancer $[16,17]$.

Over the last few decades, there has been increased interest by pharmaceutical industries to discover the new drugs from the ethnobotanicals to provide new and alternative drugs to synthetic drugs for the treatment of dreadful diseases. Stephania elegans belong to Menispermaceae family, including 65 genera and 350 species [18]. The members of this family are generally herbs or shrubs and are small climbers with peltate and membranous leaves and are generally seen in temperate and tropical regions of lower Himalayas in India, Bhutan, Burma, China and Nepal at altitudes of 2000-2200 m. These plants (especially tubers) have recognised medicinal values and traditionally have been used by locals for the treatment of asthma, tuberculosis, dysentery, hyperglycemia, cancer, fever, intestinal complaints, sleep disturbances and inflammation [19-21]. Stephania is the principal genus comprising 43 species and a lot of studies have been carried to investigate anticancer properties of diverse Stephania species [22-26]. Till date, no scientific work has been conducted on bioactivities mediated by $S$. elegans phytochemicals, however S. elegans was found to be an alkaloid rich plant, and identification of nine alkaloids have been reported [27]. These days, pharmaceutical agencies significantly relies on natural products obtained from traditional medicinal plants and also an emphasis is given on unexplored ones. The current report demonstrates novel antioxidant and anticancer activities (against MCF-7 cells) of the methanolic extract of $S$. elegans tubers.

\section{MATERIALS AND METHODS}

\section{Materials}

3-(4, 5-dimethylthiazol-2-yl)-2, 5-diphenyltetrazolium bromide) (MTT), 2-2'-azinobis (3-ethyl-benzothiazoline-6-sulfonic acid) (ABTS) 
ascorbic acid and Gallic acid were purchased from Sigma-Aldrich. Phosphate buffer saline (PBS), Dulbecco's modified Eagle medium (DMEM), fetal bovine serum (FBS), 2,4,6-tripyridyl-striazine (TPTZ), ferrous sulfate $\left(\mathrm{FeSO}_{4} .6 \mathrm{H}_{2} \mathrm{O}\right)$, trypsin, vincristine, penicillin and streptomycin were purchased from HiMedia Laboratories Pvt. Ltd. Dimethyl sulphoxide, potassium persulfate, sodium bicarbonate, Mayer's reagent, Benedict's solution, acetic anhydride lead acetate, ferric chloride, glacial acetic acid, hydrochloric acid, sulfuric acid and sodium hydroxide were purchased from Loba Chemie. All organic solvents like methanol, chloroform were of HPLC grade.

\section{Preparation of extract from S. elegans}

Plant tubers were collected from the Koti village of Solan, Himachal Pradesh, India. Botanical identification of species was done by renowned taxonomist of Y. S Parmar University, Nauni (H. P., India), identified as S. elegans and linked to UHF-Herbarium with Field book No. 13530. Dried tubers were powdered and macerated by methanol at a ratio of $1: 5(\mathrm{w} / \mathrm{v})$ for $72 \mathrm{~h}$. The extract was filtered using Whatman filter paper and then concentrated in vacuo at $40{ }^{\circ} \mathrm{C}$ using a rotary evaporator and then stored as a methanolic extract for experiments.

\section{Preliminary phytochemical screening}

The methanolic extract of $S$. elegans was screened for the presence of various families of phytoconstituents viz. Alkaloids, carbohydrates, glycosides, saponins, tannins, quinones, coumarin, amino acids, terpenoids and steroids by respective reagents using standard procedures [28-30].

\section{Quantitative determination of total phenolics}

Folin Ciocalteu reagent was used for the analysis of the total phenolic content of the methanolic extract [31]. A volume of $0.2 \mathrm{ml}$ of the extract was introduced into test tubes followed by $0.5 \mathrm{ml}$ Folin-Ciocalteu's reagent (diluted 10 times with water).

The solution was then kept in the dark for $5 \mathrm{~min}$ and then $1 \mathrm{ml}$ sodium carbonate $(7.5 \% \mathrm{w} / \mathrm{v})$ was added. After $30 \mathrm{~min}$, the absorbance of the mixture was measured by UV-vis spectrophotometer at $765 \mathrm{~nm}$ and compared to a gallic acid calibration curve. Gallic acid served as the standard for preparing the calibration curve ranging from 20 to $80 \mu \mathrm{g} / \mathrm{ml}$ assay solution. The determinations were carried out in triplicate and the total phenolic content was expressed as Gallic acid equivalents (mg of $\mathrm{GAE} / \mathrm{g}$ of sample).

\section{In vitro antioxidant assay (ABTS assay)}

ABTS assay was conducted to analyse antioxidant attributes of $S$. elegans. The ABTS ${ }^{+}$is generated by reacting an oxidizing agent (e. g. Potassium persulfate) with the ABTS salt. The reduction of the bluegreen ABTS*+ by hydrogen-donating antioxidant is calculated by the suppression of its characteristic long wave absorption spectrum and by the effect of this reaction blue ABTS radical cation is converted back to its colourless neutral form. ABTS solution was prepared by dissolving light green coloured ABTS in distilled water to get a final concentration of $7.4 \mathrm{mmol} .2 .46 \mathrm{mmol}$ potassium persulfate solution was also prepared. Then both solutions were blended rigorously in ratio 1:1 and the solution was kept in the dark for $24 \mathrm{~h}$. Further, the working solution was prepared by diluting the solution $1: 25$ in methanol [32].

Sample extract was prepared in DMSO $(1 \mathrm{mg} / \mathrm{ml})$. Ascorbic acid, a notable antioxidant was considered as a positive control and methanol was used as a blank whereas DMSO was used as negative control. To $3 \mathrm{ml}$ of $\mathrm{ABTS}^{*+}$ solution, sample extracts containing antioxidant were added at the concentrations 20, 40, 60 and 80 $\mu \mathrm{g} / \mathrm{ml}$. Absorption was taken using light absorption spectrophotometer at a wavelength of $734 \mathrm{~nm}$. The assay was performed three times, and percentage inhibition ( IC $_{50}$ value) was calculated by Graphpad Prism 5.0.2.

\section{FRAP assay}

The FRAP assay was carried out by Benzie and Strain method [33] with certain modifications. The stock solutions for the assay included $300 \mathrm{mmol}$ acetate buffer $\left(3.1 \mathrm{~g} \mathrm{C}_{2} \mathrm{H}_{3} \mathrm{NaO}_{2} .3 \mathrm{H}_{2} \mathrm{O}\right.$ and 16 $\mathrm{ml} \mathrm{C}_{2} \mathrm{H}_{4} \mathrm{O}_{2}$ ), pH 3.6, $10 \mathrm{mmol}$ TPTZ solution in $40 \mathrm{mmol} \mathrm{HCl}$ and $20 \mathrm{mmol} \mathrm{FeCl}_{3} .6 \mathrm{H}_{2} \mathrm{O}$ solution.

The fresh working solution was prepared by mixing $16 \mathrm{ml}$ acetate buffer, $2 \mathrm{ml} \mathrm{TPTZ} \mathrm{solution,} \mathrm{and} 2 \mathrm{ml} \mathrm{FeCl}_{3} \cdot 6 \mathrm{H}_{2} \mathrm{O}$ solution and then warmed at $37{ }^{\circ} \mathrm{C}$ before carrying out the experiment. Sample $(150 \mu \mathrm{l})$ was allowed to react with $2.850 \mathrm{ml}$ of the FRAP solution for $30 \mathrm{~min}$ in the dark condition. FRAP values were calculated by measuring the absorbance of coloured product [ferrous tripyridyl triazine complex] at $593 \mathrm{~nm}$ and then relating it to a ferrous ion standard solution. Results were expressed in $\mu \mathrm{M} \mathrm{TE} / \mathrm{g}$ fresh mass.

\section{Cell culturing and maintenance}

To evaluate anticancer properties of S. elegans, MCF-7 (breast carcinoma) cell line was procured from National Centre for Cell Sciences (NCCS), Pune, India. Following standard procedures, stock cells were cultured in DMEM supplemented with $10 \%$ inactivated fetal bovine serum (FBS), 1\% penicillin-streptomycin and amphotericin B $(5 \mu \mathrm{g} / \mathrm{ml})$ in a humidified atmosphere of $5 \% \mathrm{CO}_{2}$ at $37^{\circ} \mathrm{C}$ until confluent. The stock cultures were grown in $25 \mathrm{~cm}^{2}$ tissue culture flasks, and all experiments were carried out in 96 well Microtiter plates.

\section{Subculturing}

Used media were disposed of followed by a PBS wash in order to take out the dead cells and debris. Trypsinization of cells was carried out using $0.25 \%$ of trypsin. Further centrifugation was done at $2000 \mathrm{rpm}$ for $10 \mathrm{~min}$; the pellet was then cultivated.

Fresh aliquots were made and transferred to new culture dishes for sub-culturing $\left(1 * 10^{4}\right.$ viable cells/well were seeded). Cell counting was conducted using a hemocytometer, 2000 cells/well in $200 \mu \mathrm{l}$ media were seeded in a 96 well plate and further incubated for $24 \mathrm{~h}$ for optimal growth in nourished media and environment.

\section{In vitro cytotoxicity assay}

The methanolic extract of $S$. elegans was tested for in vitro cytotoxicity by using MTT reagent $(5 \mathrm{mg} / \mathrm{ml})$ [34]. Cells (2000 cells/well) were seeded in media (DMEM) in a 96 well plate followed by overnight incubation.

S. elegans extract in different concentrations $(25,50,100,200$ $\mu \mathrm{g} / \mathrm{ml}$ ) were added followed by a $24 \mathrm{~h}$ incubation. Vincristine $(10 \mu \mathrm{g} / \mathrm{ml})$ and DMSO were used as positive and negative controls, respectively. The optical density was noted at $595 \mathrm{~nm}$ using a microplate reader. IC50 values were calculated by Graphpad Prism 5.0.2.

\section{Statistical analysis}

Results were expressed as mean \pm standard error. The one-way ANOVA and multiple comparisons of 2-tails of Student's t-test (2 groups) were used to evaluate the difference between the control and test samples by the Graphpad Prism software for windows. A p value $\leq 0.05$ was considered to be significant.

\section{RESULTS}

\section{Phytochemical analysis}

$40 \mathrm{~g}$ of plant tuber powdered material yielded $4.1 \mathrm{~g}$ of methanolic extract $(10.25 \%)$. The phytochemical analysis revealed that the methanolic extract of $S$. elegans contains alkaloids, carbohydrates, flavonoids, saponins, terpenoids/steroids and tannins (table 1). The quinones, coumarin, amino acids and glycosides were absent in the plant extract. 
Table 1: Phytochemical assessment in methanolic extract of $S$. elegans (+indicates the presence and-indicates the absence of a phytochemical)

\begin{tabular}{ll}
\hline Phytochemicals & Methanolic extract of S. elegans \\
\hline Alkaloids & + \\
Carbohydrates/reducing sugars & $+/+$ \\
Flavonoids & + \\
Tannins & + \\
Terpenoids/steroids & + \\
Saponins & + \\
Amino acids & - \\
Quinone & + \\
Coumarin & - \\
Glycosides & - \\
\hline
\end{tabular}

\section{Total phenolic content (TPC)}

The total phenolic content was reported as Gallic acid equivalents (fig. 1) with reference to a standard curve (standard curve equation: $y=$ $0.0543 x+0.06847, R^{2}=0.9404$ ). The total phenolic content measured in methanolic extract was $23.0 \pm 0.06 \mathrm{mg} \mathrm{GAE} / \mathrm{g}$ of dry sample.

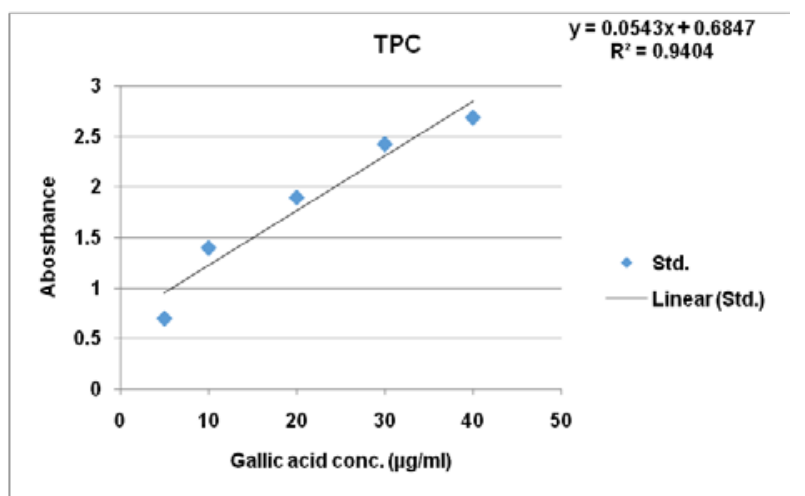

Fig. 1: Standard curve of Gallic acid for determination of total phenolic content

\section{In vitro antioxidant assay}

In vitro ABTS assay was conducted to study the antioxidant activity of $S$. elegans at a concentration range of $20-80 \mu \mathrm{g} / \mathrm{ml}$. Ascorbic acid, a well-known antioxidant compound was taken as positive control (fig. 2). As compared to ascorbic acid ( IC $_{50}$ $12.56 \pm 0.1 \mu \mathrm{g} / \mathrm{ml}$ ), S. elegans extract also showed significant antioxidant activity with an increase in concentration IC $_{50}$ $41.66 \pm 0.015 \mu \mathrm{g} / \mathrm{ml}$ ) (table 2, fig. 2). Thus the selected plant possesses high antioxidant potential.

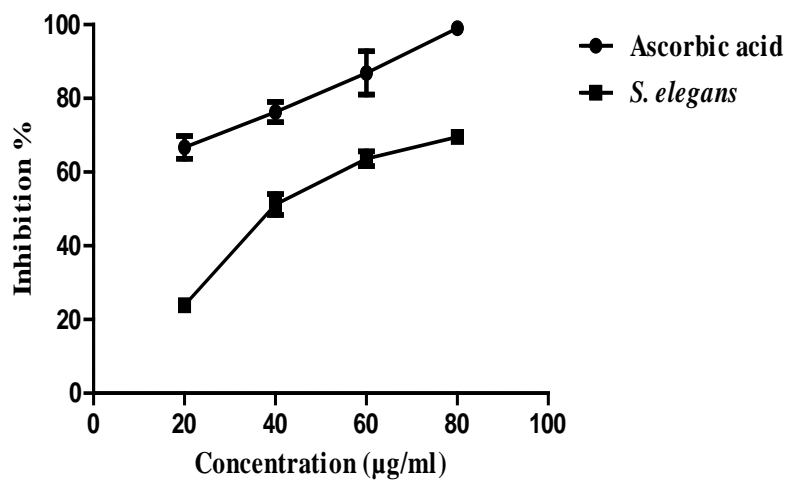

Fig. 2: Antioxidant activity of standard ascorbic acid and methanolic extract of $S$. elegans. The experiment was done twice (in triplicate) using two different samples

\section{FRAP assay}

FRAP assay was carried out, and results were compared with a standard curve of ferrous sulphate $\left(\mathrm{y}=0.0267 \mathrm{x}+0.5978, \mathrm{R}^{2}=\right.$ 0.9437) (fig. 3). The antioxidant activity of methanolic extract of $S$. elegans $(20-80 \mu \mathrm{g} / \mathrm{ml})$ as determined by FRAP assay varied from 33.33-58.76 $\mu \mathrm{M} \mathrm{TE} / \mathrm{g}$. The methanolic extract of $S$. elegans revealed significant reducing potential (IC $50 \quad 51.62 \pm 0.023 \mu \mathrm{g} / \mathrm{ml}$ ) which increased with the increase in concentration from $20-80 \mu \mathrm{g} / \mathrm{ml}$ (table 2, fig. 4).

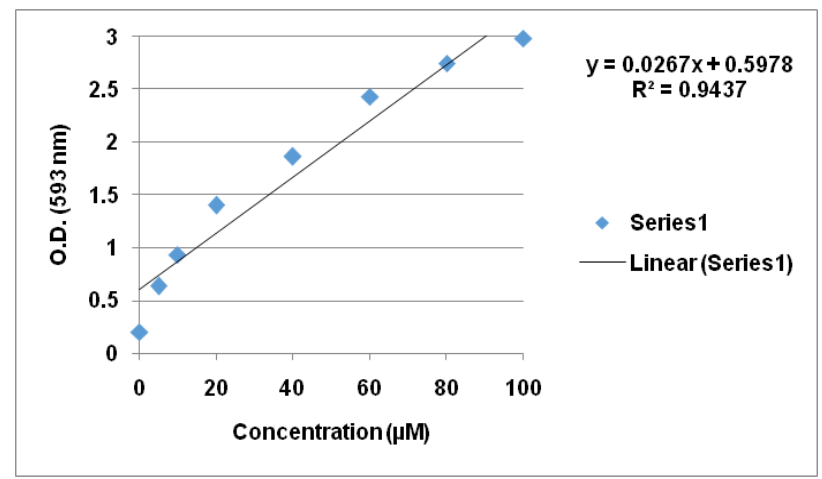

Fig. 3: Standard curve of ferrous sulphate

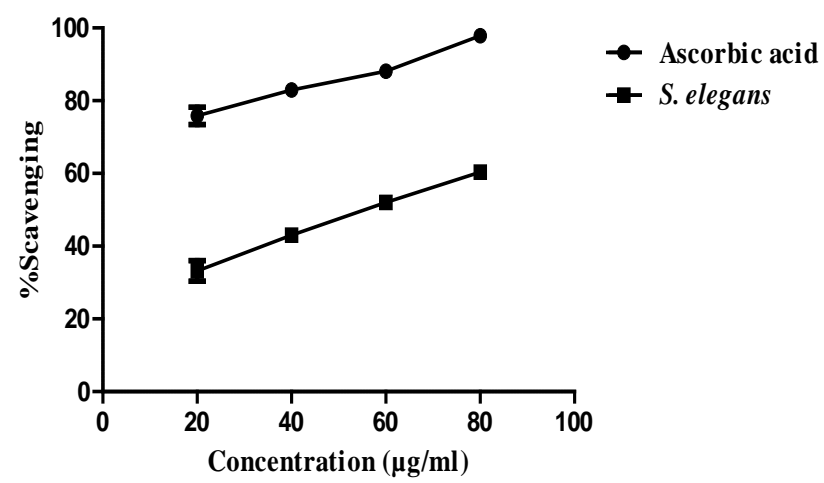

Fig. 4: Ferric reducing antioxidant power of standard ascorbic acid and methanolic extract of $S$. elegans. The experiment was done twice (in triplicate) using two different samples and data was significant as ${ }^{*} \mathbf{p}<0.05$

\section{In vitro cytotoxicity assay for MCF-7}

In vitro cytotoxicity was analysed on MCF-7 cells by MTT assay at four different drug concentrations $(25,50,100,200 \mu \mathrm{g} / \mathrm{ml}) . S$. elegans showed significant cytotoxicity from $50 \mu \mathrm{g} / \mathrm{ml}$ to $200 \mu \mathrm{g} / \mathrm{ml}$, and $\mathrm{IC}_{50}$ value was calculated as $158.7 \pm 0.13 \mu \mathrm{g} / \mathrm{ml}$ (fig. 5 ). The highest activity was recorded at $200 \mu \mathrm{g} / \mathrm{ml}$, i.e. $54 \%$. 
Table 2: \% Inhibitory concentration $\left(\mathrm{IC}_{50}\right)$ of methanolic extracts of $S$. elegans as determined by the ABTS and FRAP assays. Each value represents mean $\pm \operatorname{SEM}(n=3)$

\begin{tabular}{lll}
\hline IC $\mathbf{5 0}_{\mathbf{0}}$ value $(\boldsymbol{\mu g} / \mathbf{m l})$ & & \\
\hline Sample & ABTS & FRAP \\
\hline Ascorbic acid & $12.56 \pm 0.1$ & $7.24 \pm 0.14$ \\
S. elegans & $41.66 \pm 0.015$ & $52.96 \pm 0.024$ \\
\hline
\end{tabular}

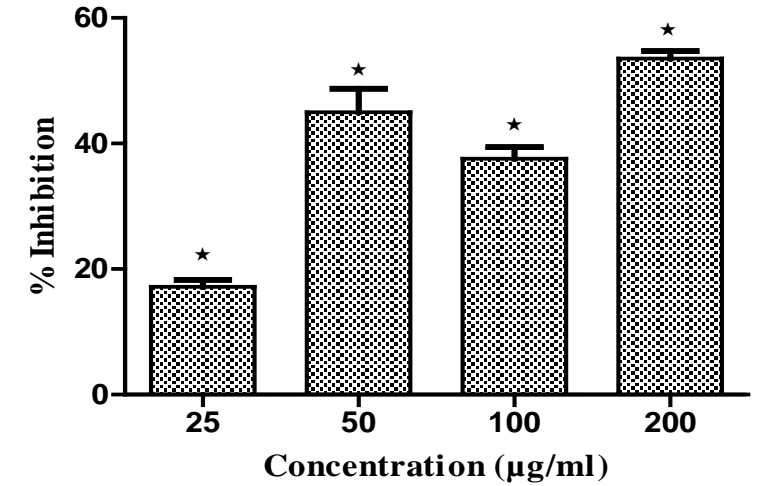

Fig. 5: Cytotoxic effect of S. elegans methanolic extract on MCF-7 cells. Experiment was done twice in triplicates at different concentrations

\section{DISCUSSION}

Cancer is one of the prominent threats to humankind. Hence, an interdisciplinary mitigating approach involving both chemical and natural sources of medications is the need of the hour. Plant-derived phytochemicals have been widely used for their immense potential to counter cancer. Herein, qualitative phytochemical screening of $S$. elegans methanolic extract indicated the presence of alkaloids, carbohydrates, tannins, saponins, terpenoids, steroids and flavonoids, which advocated this plant to be an important source for providing therapeutic agents especially for antioxidant and anticancer activity. S. elegans was elucidated for its antioxidant potential by ABTS and FRAP assays which revealed excellent radical scavenging and reducing abilities. The total phenolic content measured in the methanolic extract was $23.0 \pm 0.06 \mathrm{mg} \mathrm{GAE} / \mathrm{g}$. Polyphenolic compounds are known to have antioxidant activity, and this activity is believed to be mainly due to their redox properties, which help in adsorbing and neutralising free radicals, quenching singlet and triplet oxygen, or decomposing peroxides [35, 36]. Additionally, the alkaloids and saponins have been shown to possess immense antioxidant potential [37-39]. Plant-derived antioxidants are vitally used these days for prevention and cure of numerous disorders [40]. Earlier, ethanolic extract of S. glabra and $S$. hernandifolia have been reported to exhibit free radical scavenging activity $[41,42]$.

Cytotoxicity assay displayed promising anticancer activity of $S$. elegans methanolic extract against MCF-7 cells at a concentration range of 50 to $200 \mu \mathrm{g} / \mathrm{ml}$. Earlier, in a study of 14 plants, $S$. tetrandra demonstrated antiproliferative and proapoptotic effects in hepatic stellate cells, HSC-T6 [43]. The ethanolic extract from the tubers of $S$. venosa showed potent cytotoxicity against small human cell lung cancer (NCIH187) and human breast cancer (MCF-7), while the same extract also showed high antioxidant potential [44]. Also, cepharanthine, a biscoclaurine amphipathic alkaloid isolated from the plant $S$. cepharantha Hayata reduced mitochondrial membrane potential and upregulated the level of cleaved caspases [45]. Tetrandrine, a bis benzylisoquinoline alkaloid isolated from the roots of $S$. tetrandra S. Moore induces G1 arrest in human colon carcinomas, HT29 [46]. The phytochemical constituents such as flavonoids and terpenoids are the major components that are responsible for the potential cytotoxic activities [47-49]. Various plants possessing antioxidants, such as flavonoids, phenolic acids, carotenoids, and ascorbic acid, have been projected to be active anticancer constituents [50-52].

\section{CONCLUSION}

To the best of our knowledge, this is the first report describing the antioxidant and anticancer potential of $S$. elegans methanolic extract. The methanolic extract of $S$. elegans showed significant antioxidant activity and hence can be used as a source of natural antioxidants for curing diseases caused by oxidative stress. The study also determined the promising anticancer potential of the plant which could be used as a source of novel drug to fight cancer. Much interest is given these days towards naturally-derived photocomponents as they are considered to have less side effects compared to current treatments such as chemotherapy. Also, there is a growing demand for alternative treatments with naturally-derived anticancer agents with plants being the desired source. Medicinal plants like S. elegans can be of significant use in this context. However, further investigations need to be carried out to isolate and characterise the specific bioactive compounds responsible for such activities. Moreover, in vivo studies are also necessary to confirm the anticancer potential of this plant in more detail.

\section{ACKNOWLEDGEMENT}

The authors are grateful to Shoolini University of Biotechnology and Management Sciences, Solan, H. P., India for providing the infrastructure and facilities to conduct this research. The work was funded by "Pilot Project grant for Young Investigators in Cancer Biology", Department of Biotechnology, Govt. of India.

\section{CONFLICT OF INTERESTS}

The authors declare no conflict of interest

\section{REFERENCES}

1. Stewart BW, Wild CP. Cancer worldwide. World Cancer Report. USA; 2014.

2. Jemal A, Bray F, Center MM, Ferlay J, Ward E, Forman D. Global cancer statistics. CA Cancer J Clin 2011;61:69-90.

3. WHO. Global Status Report on Non-communicable Diseases. Geneva, Switzerland; 2011.

4. Ali Seyed M, Jantan I, Vijayaraghavan K, Bukhari SN. Betulinic acid: recent advances in chemical modifications, effective delivery and molecular mechanisms of a promising anticancer therapy. Chem Biol Drug Des 2015;87:517-36.

5. Ngugi M Piero, Njagi M Joan. Cancer: a molecular curse? Int J Curr Pharm Res 2015;7:1-3.

6. Aggarwal BB, Van Kuiken ME, Iyer LH, Harikumar KB, Sung B. Molecular targets of nutraceuticals derived from dietary spices: potential role in suppression of inflammation and tumorigenesis. Exper Biol Med 2009;234:825-49.

7. Costa-Lotufo LV, Khan MTH, Ather A, Wilke DV, Jimenez PC Pessoa C, et al. Studies of the anticancer potential of plants used in Bangladeshi folk medicine. J Ethnopharmacol 2005;99:21-30.

8. Fouche G, Cragg GM, Pillay P, Kolesnikova N, Maharaj VJ, Senabe J. In vitro anticancer screening of South African plants. J Ethnopharmacol 2008;119:455-61.

9. Kamatou GPP, Van Zyl RL, Davids H, Van Heerden FR, Lourens ACU, Viljoen AM. Antimalarial and anticancer activities of selected South African Salvia species and isolated compounds from $S$. radula. S Afr J Bot 2008;74:238-43.

10. Y Cai, Q Luo, M Sun, Corke. Antioxidant activity and phenolic compounds of 112 traditional Chinese medicinal plants associated with anticancer. Life Sci 2004;74:2157-84.

11. Willcox J, Sarah A, Catignani G. Antioxidants and prevention of chronic disease. Crit Rev Food Sci Nutr 2004;44:275-95.

12. Sireesha K, Sailaja Rao P. Oxidative stress and diabetes: an overview. Asian J Pharm Clin Res 2015;8:15-9.

13. Klaunig JE, Kamendulis LM. The role of oxidative stress in carcinogenesis. Ann Rev Pharmacol Toxicol 2004;44:239-67. 
14. Dizdaroglu M, Jaruga P, Birincioglu M, Rodriguez H. Freeradical-induced damage to DNA: mechanisms and measurement. Free Radical Biol Med 2002;32:1102-15.

15. Glasauer A, Chandel NS. Targeting antioxidants for cancer therapy. Biochem Pharmacol 2014:92:90-101.

16. Seeram NP, Adams LS, Zhang Y, Lee R, Sand D, Scheuller HS, et al. Blackberry, black raspberry, blueberry, cranberry, red raspberry, and strawberry extracts inhibit growth and stimulate apoptosis of human cancer cells in vitro. J Agric Food Chem 2006;54:9329-39.

17. Zhang Y, Seeram NP, Lee R, Feng L, Heber D. Isolation and identification of strawberry phenolics with antioxidant and human cancer cell antiproliferative properties. J Agric Food Chem 2008;56:670-5.

18. Deepak Kumar Semwal, Ruchi Badoni, Ravindra Semwal, Sudhir Kumar Kothiyal, Gur Jas Preet Singh, Usha Rawat. The genus Stephania (Menispermaceae): chemical and pharmacological perspectives. J Ethnopharmacol 2010;132:369-83.

19. Kirtikar KR, Basu BD. Indian Medicinal Plants. 2nd ed. Allahabad: L. M. Basu; 2004. p. 94.

20. Gaur RD. Flora of District Garhwal North West Himalaya. 1st ed. Srinagar Garhwal, India: Trans Media; 1999. p. 76-7.

21. Chopra RN, Chopra IC, Handa KL, Kapur LD Chopra. Indigenous Drugs of India. 2nd ed. Calcutta, India: Char UN and Sons Ltd; 1958. p. 412 .

22. Hong De $\mathrm{Xu}$, Soon-Chang Cho, Mi-Ae Bang, Chun-Sik Bae, Yeon Shik Choi, Yong-Chun Li, et al. FK-3000 isolated from Stephania delavayi Diels. Inhibits MDA-MB-231 cell proliferation by decreasing NF- $\mathrm{BB}$ phosphorylation and COX-2 expression. Int J Oncol 2015;46:2309-16.

23. Moongkarndi P, Kosem N, Luanratana O, Jongsomboonkusol S, Pongpan N. Antiproliferative activity of thai medicinal plant extracts on human breast adenocarcinoma cell line. Fitoterapia 2004;75:375-7.

24. Nakaoji K, Nayeshiro H, Tanahashi T, Su Y, Nagakura N. Bisbenzylisoquinoline alkaloid from Stephania cepharantha and their effects on proliferation of cultured cell from the Murine hair apparatus. Planta Med 1997;63:425-8.

25. Montririttigri K, Moongkarndi P, Joongsomboonkusol S, Chitkul B, Pattanapanyasat K. Apoptotic activity of aporphine from Stephania venosa on human ovarian cancer cells. Mahidol Univ J Pharm Sci 2008;35:52-6.

26. Yang DL, Mei WL, Dai HF. Cytotoxic alkaloids from the tuber of Stephania succifera. Chin J Med Chem 2010;20:206-10.

27. Singh RS, Kumar P, Bhakuni DS. The Alkaloids of Stephania elegans. J Nat Prod 1981;44:664-7.

28. Sofowara A. Medicinal plants and traditional medicine in Africa. Ibadan, Nigeria: Spectrum Books Ltd; 1993. p. 191-289.

29. Trease GE, Evans WC. Pharmacognosy. 11th ed. London: Bailliere Tindall; 1989. p. 45-50.

30. Harborne JB. Phytochemical methods. 2nd ed. London, NewYork: Chapman and Hall publications; 1984. p. 288.

31. Singleton VL, Orthofer R, Lamuela Raventos RM. Analysis of total phenols and other oxidation substrates and antioxidants by means of Folin-Ciocalteu reagent. Methods in Enzymol 1999;299:152-78.

32. Kriengsak Thaipong, Unaroj Boonprakob, Kevin Crosby, Luis Cisneros-Zevallos, David Hawkins Byrne. Comparison of ABTS, DPPH, FRAP, and ORAC assays for estimating antioxidant activity from guava fruit extracts. J Food Comp Anal 2006;19:669-75.

33. Benzie IF, Strain JJ. The ferric reducing ability of plasma (FRAP) as a measure of "antioxidant power": the FRAP assay. Anal Biochem 1996;239:70-6.

34. Scudiero DA, Shoemaker RH, Paull KD, Monks A, Tierney S, Nofziger TH, et al. Evaluation of a soluble tetrazolium/formazan assay for cell growth and drug sensitivity in culture using human and other tumor cell lines. Cancer Res 1988;48:4827-33.
35. B Tepe, M Sokmen, HA Akpulat, A Sokmen. Screening of the antioxidant potentials of six Salvia species from Turkey. Food Chem 2006;95:200-4

36. W Zheng, SY Wang. Antioxidant activity and phenolic compound in selected herbs. J Agric Food Chem 2001:49:5165-70.

37. Fadila Maiza Benabdesselam, Sabiha Khentache, Khalida Bougoffa, Mohamed Chibane, Sandrine Adach, Yves Chapeleur, et al. Antioxidant activities of alkaloid extracts of two Algerian species of Fumaria; Fumaria capreolata and Fumaria bastardii. Rec Nat Prod 2007;1:2-3,28-35.

38. Soon Huat Tiong, Chung Yeng Looi, Hazrina Hazni, Aditya Arya, Mohammad javad Paydar, Won Fen Wong, et al. Antidiabetic and antioxidant properties of Alkaloids from Catharanthus roseus (L.) G. Don. Molecules 2013;18:9770-84.

39. Lokesh Ravi, Manasvi V, Praveena Lakshmi B. Antibacterial and antioxidant activity of saponin from Abutilon Indicum leaves. Asian J Pharm Clin Res 2016;9:1-4.

40. Mayura A Kale, Suparna M Bindu, Pratima Khadkikar. Role of antioxidants and nutrition in oxidative stress: a review. Int J Appl Pharm 2015;7:1-4.

41. Singh Lubhan, Najmi Abul Kalam, Sara Udai Veer Singh, Majhi Sagarika. In vitro antioxidant activity of ethanolic extract of Stephania Glabra (Roxb) mier tubers. Pharma Res 2014;12:1-11.

42. Sharma U, Sahu RK, Roy A, Golwala DK. In vivo antidiabetic and antioxidant potential of Stephania hernandifolia in streptozotocin-induced-diabetic rats. J Young Pharm 2010;2:255-60.

43. SY Chor, AY Hui, KF To, KK Chan, YY Go, HLY Chan, et al. Antiproliferative and pro-apoptotic effects of herbal medicine on the hepatic stellate cell. J Ethnopharmacol 2005;100:180-6.

44. Leewanich P, Worachartcheewan A, Prachayasittikul S, Prachayasittikul V. Anticancer and antioxidative activies of Stephania venosa. Eur J Sci Res 2011;51:150-6.

45. Tomofumi Uto, Masaaki Toyama, Keisuke Yoshinaga, Masanori Baba. Cepharanthine induces apoptosis through the mitochondria/caspase pathway in murine dendritic cells. Immunopharm Immunot 2016;38:238-43.

46. Meng LH, Zhang H, Hayward L, Takemura H, Shao RG, Pommier Y. Tetrandrine induces early. G1 arrest in human colon carcinoma cells by down-regulating the activity and inducing the degradation of G1-S-specific cyclin-dependent kinases and by inducing p53 and p21Cip1. Cancer Res 2004;64:9086-92.

47. Rathinam Prema, Dhana Sekaran Sathish Sekar, Kothapalli Bannoth Chandra Sekhar, Somasundaram Jeevanandham. In vitro cytotoxicity study on combined plants extracts (Cissus quadrangularis and Aegle marmelos). Eur J Exp Biol 2012;2:882-8.

48. Matsuo M, Sasaki N, Saga K, Kaneko T. Cytotoxicity of flavonoids toward cultured normal human cells. Biol Pharm Bull 2005;28:253-9.

49. Neerja Gupta, Saxena G, Kalra SS. Antimicrobial activity pattern of certain terpenoids. Int J Pharm Biol Sci 2011;1:87-91.

50. Birt DB, Hendrich S, Wang W. Dietary agents in cancer prevention: Flavonoids and isoflavonoids. Pharmacol Thera 2001;90:157-77.

51. Mullick T, Gasser E. Nutrition in the chemoprevention of gastrointestinal cancer: Where are we in the new millennium. Nutrition issues in the gastroenterology. Pract Gastroenterol 2004;15:52-64.

52. Zulak K, Liscombe D, Ashihara H, Facchini P. Alkaloids. Plant secondary metabolism in diet and human health. Oxford: Blackwell Publishing; 2006. p. 102-36.

\section{How to cite this article}

- $\quad$ Ravin Sharma, Gourav Chandan, Anterpreet Chahal, Reena V Saini. Antioxidant and anticancer activity of methanolic extract from Stephania elegans. Int J Pharm Pharm Sci 2017;9(2):245-249. 